\title{
Experimental Study on the Cause of Inorganic Scale Formation in the Water Injection Pipeline of Tarim Oilfield
}

\author{
Guihong Pei, ${ }^{1}$ Chunyang Wang, ${ }^{2}$ and Lili Liu' \\ ${ }^{1}$ School of Civil Engineering and Architecture, Southwest Petroleum University, Chengdu 610500, China \\ ${ }^{2}$ College of Engineering, Lyceum-Northwestern University, 2400 Dagupan, Philippines \\ Correspondence should be addressed to Guihong Pei; 570769297@qq.com
}

Received 14 July 2014; Revised 16 November 2014; Accepted 16 November 2014; Published 4 December 2014

Academic Editor: José Morillo

Copyright (c) 2014 Guihong Pei et al. This is an open access article distributed under the Creative Commons Attribution License, which permits unrestricted use, distribution, and reproduction in any medium, provided the original work is properly cited.

\begin{abstract}
Scale formation of water injection pipeline will cause the pipeline to be corroded and increase frictional drag, which will induce the quality and quantity cannot meet the need of oil production process. The cause of scale formation in different oilfield is different because of the complex formation conditions. Taking one operation area of Tazhong oilfield as research object, the authors studied the water quality in different point along water injection pipeline through experiment studies, and analyzed the cause of inorganic scale formation and influence factors. The research results can provide theoretical guidance to anticorrosion and antiscale of oilfield pipeline.
\end{abstract}

\section{Introduction}

Oilfield produced water mainly refers to prolapsed sewage in the crude oil production process. It is common that the oilfield produced water is used as injected water to enhance the oil recovery in the water flooding development process. However, poor quality injected water will lead to scale formation and corrosion in the water injection pipeline, which can induce the oil production [1-3].

It is known that the common scaling of oil pipeline is calcareous carbonic, calcium sulfate, barium sulfate, strontium sulfate, also including corrosion products (ferrous sulfide, ferrous sulfate) and precipitates which have high solubility, high content under certain conditions [4], which are mainly caused by the following four reasons. (1) Mixing the injection water and formation water will cause scaling. There are rich sulfates in seawater and calcium ions, magnesium ions in formation water, which will cause calcium sulfate and magnesium sulfate when mixing. (2) Automatic scaling reservoir water and oil coexisted; various production processes inevitably lead to the changes of equilibrium. If this change makes fluid components over a mineral solubility limit, it will produce the scale deposition sulfate and carbonate, due to changing the temperature and pressure or the deposition of hampered flow; high salinity brine temperature substantially falls; they will lead to halide precipitation crystallization. (3) The scaling that evaporation caused and produced hydrocarbon gas in the process of mining relates to formation water. With the production of pipe hydrostatic pressure decreases, the volume of hydrocarbon gas will increase and the higher temperature of the brine will evaporate, so that the remaining dissolved ions concentration is more than solubility product of the mineral substance leading to scaling. (4) When gas drive or chemical flooding produced scaling by carbon dioxide flooding to take the tow times extracting oil, acidic water which contains carbon dioxide and dissolution of calcite formed the dynamic balance [5-8].

Combining the four factors above and considering that the mineralogical composition in the oilfield produced water varies in the different districts [9-11], it is essential to carry out experimental research on the compositions of the injected water and corrosion mechanism in the specific oilfield, for example, Tazhong oilfield in Xinjiang, China studied in this paper. Then, the trend of the water injection system scaling and corrosion is predicted, which benefits to prevent these negative factors reducing the oil recovery. 


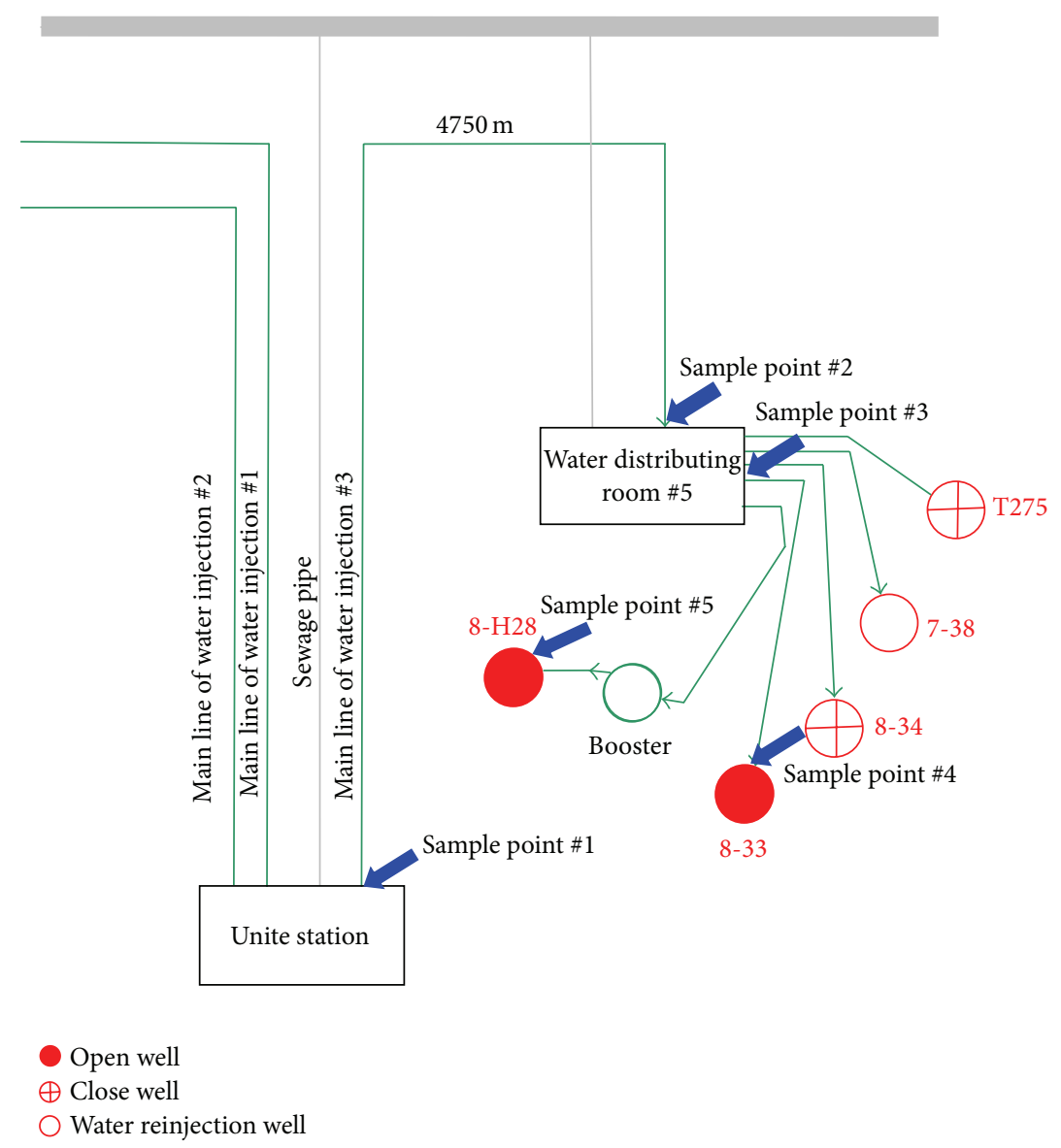

FIGURE 1: Schematic diagram of water and scale sampling positions.

\section{Material and Method}

2.1. Source of Water and Scale Samples. The water sample and the scaling sample are extracted in the reinjection water pipeline at different distances from Union Station in site. In order to study the effect between water quality in water injection pipeline and scale sample, we take water sample at different positions at the number 3 water injection pipeline as the research object. The sampling points map was shown in Figure 1.

2.2. Experimental Method of Water and Scale Samples. According to influence factors of oilfield reinjection water corrosion and scaling, further quantitative test on the reinjection water in Tazhong oilfield is conducted to identify the main factors of scaling and corrosion. The test method of the main inorganic ions, which influence scaling and corrosion which are $\mathrm{Ca}^{2+}, \mathrm{Mg}^{2+}, \mathrm{Cl}^{-}, \mathrm{SO}_{4}{ }^{2-}, \mathrm{Ba}^{2+}, \mathrm{CO}_{3}{ }^{2-}, \mathrm{HCO}_{3}{ }^{-}$, $\mathrm{OH}^{-}, \mathrm{K}^{+}, \mathrm{Na}^{+}, \mathrm{S}^{2-}$, are shown in Table 1 .

The analysis methods of main organic matters which influence oilfield reinjection water scaling and corrosion: COD, TOC, suspended solid, oil, the analysis method, are shown in Table 2.

Bacteria analysis in oilfield reinjection water is conducted based on (water injection bacterial analysis method) SY/T 0532-93[13].

\section{Results and Discussions}

3.1. Results of Water Samples and Discussions. Water quality test results are shown in Table 3.

According to the test results in Table 3, we can find the following. (1) The suspended matter content of number 1 to number 5 water samples are all above $100 \mathrm{mg} / \mathrm{L}$, far greater than the minimum requirements of oilfield reinjection water (value $<10 \mathrm{mg} / \mathrm{L}$ ). Suspended matter content seriously exceeding the standard is one of the main reasons of water injection pipeline scaling. Therefore, reducing the suspended matter content can be used as one of the ways to control fouling. (2) The original water concentration of COD is $40-80 \mathrm{mg} / \mathrm{L}$. Because the original effluent water quality drops badly, the content of crude oil in water after original process will be high. For the crude oil in water, we can control the content of crude oil by the methods of adding water, sedimentation, and filtration. (3) Seen from the analysis result, the content of calcium ion is in 4.00-5.25 g/L. The test results of calcium ions are higher than the test results (calcium concentration $3.7 \mathrm{~g} / \mathrm{L}$ ) of water quality in 2009 . (4) The content of $\mathrm{Mg}^{2+}, \mathrm{Ba}^{2+}$, and $\mathrm{Sr}^{2+}$ is $0.367-0.581 \mathrm{~g} / \mathrm{L}$, $0.060-0.294 \mathrm{~g} / \mathrm{L}$, and $0.230-0.295 \mathrm{~g} / \mathrm{L}$, respectively. Owing to the percentage composition of $\mathrm{Mg}^{2+}, \mathrm{Ba}^{2+}$, and $\mathrm{Sr}^{2+}$ ions being much lower than that of calcium, $\mathrm{Ca}^{2+}$ is supposed as 
TABLE 1: Water inorganic ion analysis method.

\begin{tabular}{|c|c|c|c|}
\hline Element & Method & $\begin{array}{l}\text { Reference } \\
\text { method }\end{array}$ & LOD \\
\hline Chloride & $\begin{array}{l}\text { Mohr/colorimetric } \\
\text { method }\end{array}$ & ASTM D4458 & $0.5 \mathrm{mg} / \mathrm{L}$ \\
\hline Basicity & Potentiometry & $\begin{array}{c}\text { ASTM D } \\
1067\end{array}$ & $1 \mathrm{mg} / \mathrm{L}$ \\
\hline Ammonia & Titrimetry & GB/T 7478 & $\begin{array}{l}\text { nitrogen } \\
0.2 \mathrm{mg} / \mathrm{L}\end{array}$ \\
\hline Barium & $\begin{array}{l}\text { Atomic absorption } \\
\text { method }\end{array}$ & $\begin{array}{c}\text { GB/T } 15506 \\
\text { ASTM D } 3651 \\
\end{array}$ & $1.7 \mathrm{mg} / \mathrm{L}$ \\
\hline Calcium & $\begin{array}{l}\text { Atomic absorption } \\
\text { method EDTA titration }\end{array}$ & $\begin{array}{l}\text { GB/T } 11905 \\
\text { GB/T } 7476 \\
\end{array}$ & $\begin{array}{c}0.02 \mathrm{mg} / \mathrm{L} \\
1 \mathrm{mg} / \mathrm{L}\end{array}$ \\
\hline Ferrum & $\begin{array}{l}\text { Atomic absorption } \\
\text { method } \\
\text { o-phenanthroline } \\
\text { spectrophotometric } \\
\text { method }\end{array}$ & $\begin{array}{c}\text { GB/T } 11911 \\
\text { ASTM D } \\
1068\end{array}$ & \\
\hline Magnesium & $\begin{array}{l}\text { Atomic absorption } \\
\text { method }\end{array}$ & GB/T 11905 & $0.0005 \mathrm{mg} / \mathrm{L}$ \\
\hline Potassium & $\begin{array}{l}\text { Atomic absorption } \\
\text { method }\end{array}$ & GB/T 11904 & $0.05 \mathrm{mg} / \mathrm{L}$ \\
\hline Sodium & $\begin{array}{l}\text { Atomic absorption } \\
\text { method }\end{array}$ & GB/T 11904 & $0.02 \mathrm{mg} / \mathrm{L}$ \\
\hline Strontium & $\begin{array}{l}\text { Atomic absorption } \\
\text { method }\end{array}$ & SY/T 5982 & $0.03 \mathrm{mg} / \mathrm{L}$ \\
\hline Sulfide & Iodometry & $\mathrm{HJ} / \mathrm{T} 60$ & $0.4 \mathrm{mg} / \mathrm{L}$ \\
\hline
\end{tabular}

TABLE 2: Analysis method of organic matter.

\begin{tabular}{lccc}
\hline Element & Method & $\begin{array}{c}\text { Reference } \\
\text { method }\end{array}$ & LOD \\
\hline COD & $\begin{array}{c}\text { Open reflux } \\
\text { method } \\
\text { High frequency } \\
\text { infrared }\end{array}$ & ASTM D 1252 & $1 \mathrm{mg} / \mathrm{L}$ \\
TOC & Filtration 13193 & $0.5 \mathrm{mg} / \mathrm{L}$ \\
$\begin{array}{l}\text { Total suspended } \\
\text { solid }\end{array}$ & GB/T 11901 & \\
\hline
\end{tabular}

negligible factor for scaling formation. (5) The $\mathrm{pH}$ value of the number 1 sample is 5.5 , and $\mathrm{pH}$ value of the numbers 2 , 3,4 , and 5 samples is 6 . The $\mathrm{pH}$ value of the oilfield water injection is 6.6 in 2009. So the reinjection water is weak acid in Tazhong oilfield. Although the lower $\mathrm{pH}$ value can make the scaling tendency reduce, elevate $\mathrm{pH}$, and increase scaling tendency, the lower $\mathrm{pH}$ will cause the pipeline inner wall exposed to the acidic environment cause corrosion. (6) The concentration of sulfide is up to $300 \mathrm{mg} / \mathrm{L}$ before the transformation and the sulfide concentration is $15 \mathrm{mg} / \mathrm{L}$ after the transformation; the higher content is one of the causes of pipeline corrosion. (7) The concentration of chloride ion is about $55 \mathrm{~g} / \mathrm{L}$ in Tazhong oilfield; the higher concentration of chlorine ion is the main pipeline corrosion factor. (8) The oxygen content in Tazhong oilfield water injection line is 0 . (9) The sulfate reducing bacteria and iron bacteria are not detected in the water injection pipeline.
TABLE 3: Water quality test results (g/L).

\begin{tabular}{lccccc}
\hline Project & $\# 1$ & $\# 2$ & $\# 3$ & $\# 4$ & $\# 5$ \\
\hline $\mathrm{CO}_{3}{ }^{2-}, \mathrm{HCO}_{3}{ }^{-}$ & 0.558 & 0.217 & 0.178 & 0.176 & 0.178 \\
$\mathrm{Ba}^{2+}$ & 0.060 & 0.139 & 0.136 & 0.294 & 0.134 \\
$\mathrm{Sr}^{2+}$ & 0.230 & 0.289 & 0.284 & 0.295 & 0.291 \\
$\mathrm{Ca}^{2+}$ & 4.050 & 4.849 & 5.100 & 5.251 & 5.062 \\
$\mathrm{Mg}^{2+}$ & 0.367 & 0.431 & 0.576 & 0.449 & 0.581 \\
$\mathrm{Cl}^{-}$ & 55.800 & 56.810 & 56.450 & 55.160 & 55.320 \\
$\mathrm{pH}^{+}$ & 5.600 & 6.000 & 6.000 & 6.000 & 6.000 \\
$\mathrm{~K}^{+}$ & 1.046 & 1.046 & 0.338 & 0.437 & 0.337 \\
$\mathrm{Na}^{+}$ & 44.409 & 96.500 & 61.500 & 95.300 & 74.601 \\
$\mathrm{SO}_{4}{ }^{2-}$ & 0.511 & 0.662 & 0.613 & 0.621 & 0.621 \\
$\mathrm{Fe}$ & 0.004 & 0.007 & 0.004 & 0.003 & 0.004 \\
$\mathrm{Sulfide}_{\mathrm{TSP}}$ & 0.301 & 0.014 & 0.014 & 0.015 & 0.017 \\
$\mathrm{COD}^{-}$ & 0.140 & 0.137 & 0.134 & 0.124 & 0.111 \\
$\mathrm{NO}_{3}{ }^{-}$ & 4.158 & 4.982 & 5.029 & 5.045 & 5.111 \\
Oxygen & 0.004 & 0.0001 & 0.001 & 0.000 & 0.000 \\
\hline
\end{tabular}

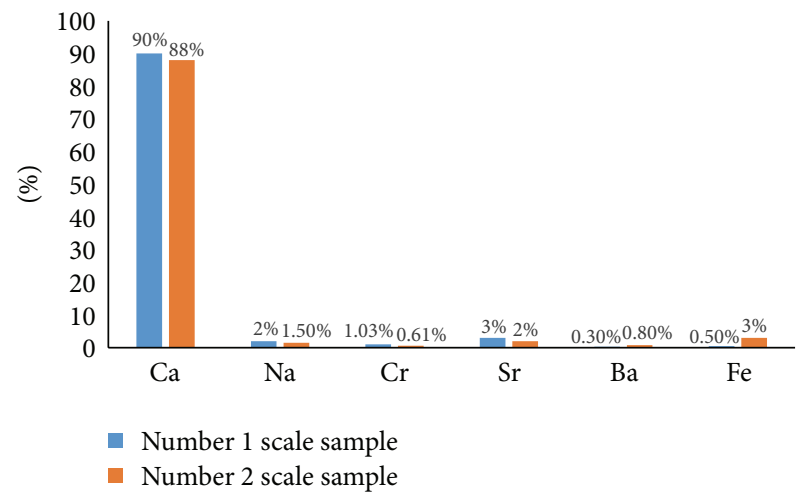

Figure 2: Metal atoms content in number 1 and number 2 scale sample.

3.2. Scale Sample Test Results and Discussions. The qualitative analysis of metal atoms in Tazhong oilfield reinjection water was tested by atomic emission spectrometry. The results are shown in Figure 2.

For the calcium carbonate of scale, iron and strontium carbonate were analyzed: calcium carbonate is $90 \%$, strontium carbonate is $3 \%$, sand is $3 \%$, and the others are $3 \%$ (including the oil which is not washed). The analysis method of number 2 scale sample is the same as that of the number 1 scale sample; through testing, the calcium carbonate of number 2 scale sample is $88 \%$, iron is $3 \%$, and $\mathrm{Sr}$ is $2 \%$.

From the testing results of scale samples, we can find the following. (1) The calcium carbonate is the main cause of oilfield water injection pipeline scaling. The results are the same as analysis of water quality. (2) The strontium content of number 1 scale sample is $3 \%$; magnesium, iron, and barium content are less; the scale is almost not containing magnesium and barium. The iron content of number 2 scale sample is $3 \%$; iron content is higher than that of iron ions in water at a percentage of total cations, and there is a certain degree of 
corrosion; ferrous sulfide scaling also blocks the pipeline. So we should fundamentally solve the scaling and control the corrosion problem.

\section{Conclusions}

According to the water quality analysis, the high calcium content in the reinjection water is the main cause of water injection pipeline scaling. So the scale inhibitors which have inhibiting effect of calcium carbonate are chosen to protect the water injecting pipeline. The water is acidic and chlorine ion concentration is high when $\mathrm{pH}$ value of injection water is $[5.6,6.0]$, which are the main causes of pipeline corrosion factor. Besides, a small amount of sulfide in water will produce hydrogen sulfide under acidic conditions, which is also one of the reasons causing corrosion.

\section{Conflict of Interests}

The authors declare that there is no conflict of interests regarding the publication of this paper.

\section{Acknowledgments}

This paper is financially supported by Natural Science Foundation of China (Grant no. 51174170) and National Science and Technology Major Project of China under Grant no. 2011ZX05013-006.

\section{References}

[1] A. Henry, J. Stiff, and L. E. Davis, "A method for predicting the tendency of oilfield waters to deposit calcium carbonate," Journal of Petroleum Technology, vol. 4, no. 9, pp. 213-216, 1952.

[2] X. Fei, W. Ming, and C. Xu, "Scale and corrosion mechanism of oilfield water injection system," Oil \& Gas Storage and Transportation, vol. 29, no. 12, pp. 896-899, 2010.

[3] M.-X. Zhang, S.-H. Wang, J.-K. Ren, J.-J. Qi, and J.-K. Zhang, "Scale formation and control in water injection wells at Baibao oil field in Changqing," Oilfield Chemistry, vol. 25, no. 2, pp. 141$157,2008$.

[4] J. E. Oddo and M. B. Tomson, "Why scale forms and how to predict it," SPE Production and Facility, vol. 9, no. 1, pp. 47-54, 1994.

[5] J. Liu, P. Han, and A. Nakayama, "Numerical simulation on the effect of filled granule shape on fracture seepage," in Geomechanics and Geotechnics: From Micro to Macro, vol. 1-2, pp. 415-419, Taylor \& Francis, 2011.

[6] J. Liu and Q. Li, "Numerical simulation of injection water flow through mudstone interlayer in low permeability oil reservoir development," Disaster Advances, vol. 5, no. 4, pp. 1639-1645, 2012.

[7] J. Liu, Y. Sano, and A. Nakayama, "A simple mathematical model for determining the equivalent permeability of fractured porous media," International Communications in Heat and Mass Transfer, vol. 36, no. 3, pp. 220-224, 2009.

[8] L. Qingjin, Y. Liuan, and S. Fuchan, "Scaling factors and scale composition in water flooding and gathering pipelines in Qinghai oilfield," Journal of Yangtze University, vol. 25, no. 2, pp. 34-37, 2005.
[9] W. Qing, "Research on corrosion fouling mechanisms of water injection system of dongxin oil field," Corrosion \& Protection in Petroleum Industry, vol. 24, no. 1, pp. 25-28, 2007.

[10] F. Wang, C. Xueyuan, and J. Su, "Prediction of scaling tendency in water injection systems at Lunnan oilfield in Tarim," Oilfield Chemistry, vol. 16, no. 1, pp. 31-33, 1999.

[11] S. Xu, X. Su, and Y. Huang, "Influencing factors on oilfield injection scaling," Journal of Xinxiang University, vol. 29, no. 2, pp. 123-127, 2012. 



\section{Carbohydrate} Chemistry

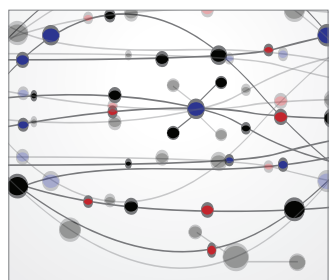

The Scientific World Journal
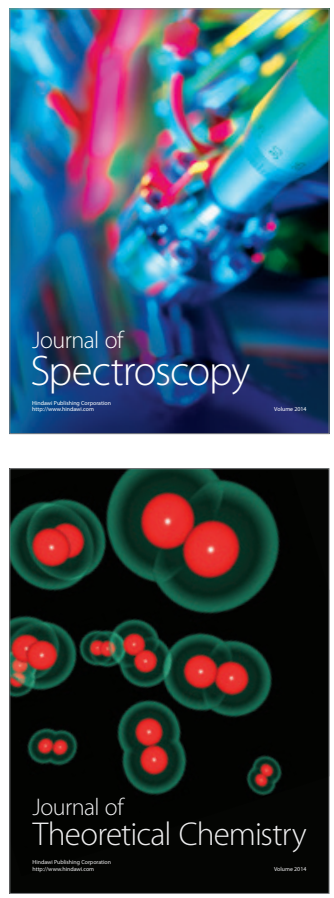
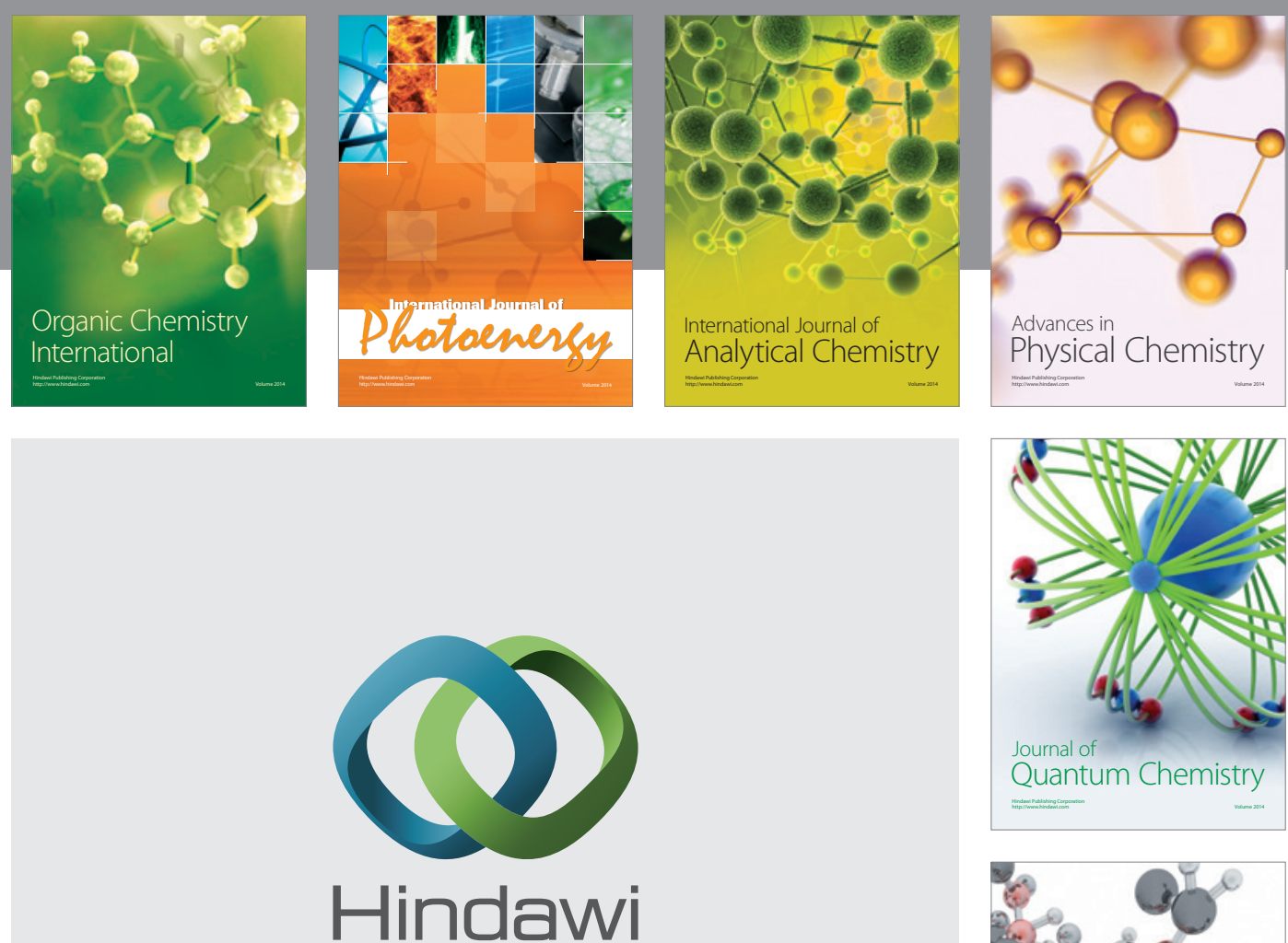

Submit your manuscripts at

http://www.hindawi.com

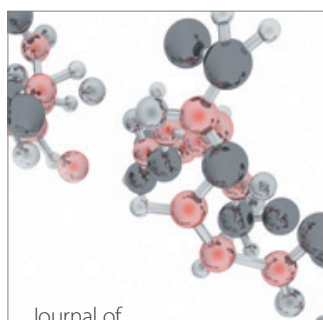

Analytical Methods

in Chemistry

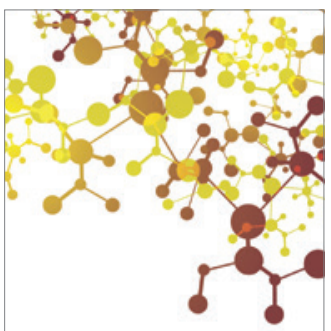

Journal of

Applied Chemistry

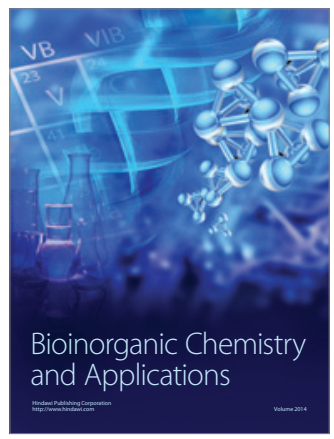

Inorganic Chemistry
